\title{
Mielen ja ruumiin pyörteissä. Kokemuksellisuus Kati Kovácsin sarjakuvateoksessa Karu selli
}

Mustasukkainen vaimo epäilee miehellään olevan suhde nuoren opiskelijatytön kanssa. Arkisten kotitöiden lomassa hän alkaa suunnitella kostotoimenpiteitä, jotka konkretisoituvat tytön murhassa (ks. Kuva 1). Veriteko tapahtuu yön pimeydessä, kauhistuneen täysikuun valvoessa aution kaupungin yllä. Kohtaus näytetään Kati Kovácsin sarjakuvateoksessa Karu selli (1996, tästä eteenpäin KS), jonka tarina välittyy retrospektiivisesti kertovan minän kautta. Teos ei pelkisty murhaan päätyväksi mustasukkaisuusdraamaksi, vaan murha toimii sysäyksenä päähenkilön psyykkiselle ja moraaliselle kehitykselle. Tarinan edetessä elinkautiseen vankeusrangaistukseen tuomittava päähenkilö, Annabella, joutuu pohtimaan tekoaan vankilaterapeutin avulla ja reflektoimaan suhdettaan aviomieheensä, äitiinsä, muihin vankeihin ja lopulta myös itseensä. Teoksen lopussa Annabella herää koomasta, jossa hän on maannut vuoden ajan loukkaannuttuaan vakavasti. Loppuratkaisu muuttaa aiemmin esitetyt tapahtumat, kuten murhan ja vankeusrangaistuksen, päähenkilön mielen kuvitteellisiksi tuotoksiksi. Konkreettisesti liikkuvuutta rajoittava rangaistuslaitos onkin mielen vankila, josta pääsee pois vasta itseymmärryksen saavutettuaan. Kertomuksen lopussakaan ei ole varmuutta siitä, mikä tapahtui todella ja mikä ainoastaan päähenkilön mielessä. Toistuva kehämäisyys ja ruumiin ja mielen suhteen tematisoituminen ohjaavat kysymään, miten teoksen rakenteelliset ja kerronnalliset ratkaisut tukevat tarinan kerroksellisuutta.

Artikkelissa osoitan, kuinka Kovácsin teos haastaa käsityksen sarjakuvasta lineaarisena ruutujen jatkumona, sillä teos koostuu perinteisiin ruudukoihin aseteltujen ruutujen lisäksi kokeellisemmista sivusommitteluista. Väitän, että sivusommittelut tuottavat tarinaan kokemuksellisuuden tason, joka ei välity tarkasteltaessa yksittäisiä ruutuja tai lineaarisia ruutujonoja. Ruutujen peräkkäisyydestä johtuen sarjakuvaa kerrontavälineenä on usein verrattu elokuvakerrontaan. On ehdotettu, että elokuva on ennen projisointia hyvin hidas sarjakuva (McCloud 1993, 8), ja että sarjakuvat ovat elokuvia ilman ääntä ja liikettä (Potsch \& Williams 2012, 13). Vaikka kuvien peräkkäisyys yhdistää esitysmuotoja, välineiden liiallinen vertailu väistämättä myös kätkee sarjakuvan erityispiirteet ja sellaiset tilallisuuden mahdollistamat kerronnalliset kokeilut, jotka elokuvakerronnassa olisivat haasteellisia tai jopa mahdottomia. Lineaarisuuden korostamisen sijaan näkökulmani huomioi sarjakuvan sivut tilallisina yksikköinä, joiden lukeminen ja tulkitseminen edellyttävät lukijalta osa-kokonaisuus- 
suhteiden tarkastelua. Näkökulmani perustuu sarjakuvatutkimuksessa esitettyyn ajatukseen sarjakuvakerronnan tilallis-paikallisuudesta ja narratologisiin keskusteluihin kertomuksista inhimillisen kokemuksen kuvaajina. Kovácsin teokseen keskittymällä osoitan, kuinka monitasoista ja monimerkityksistä kerrontaa sarjakuvan sivu voi tilallisella rakenteella tuottaa.

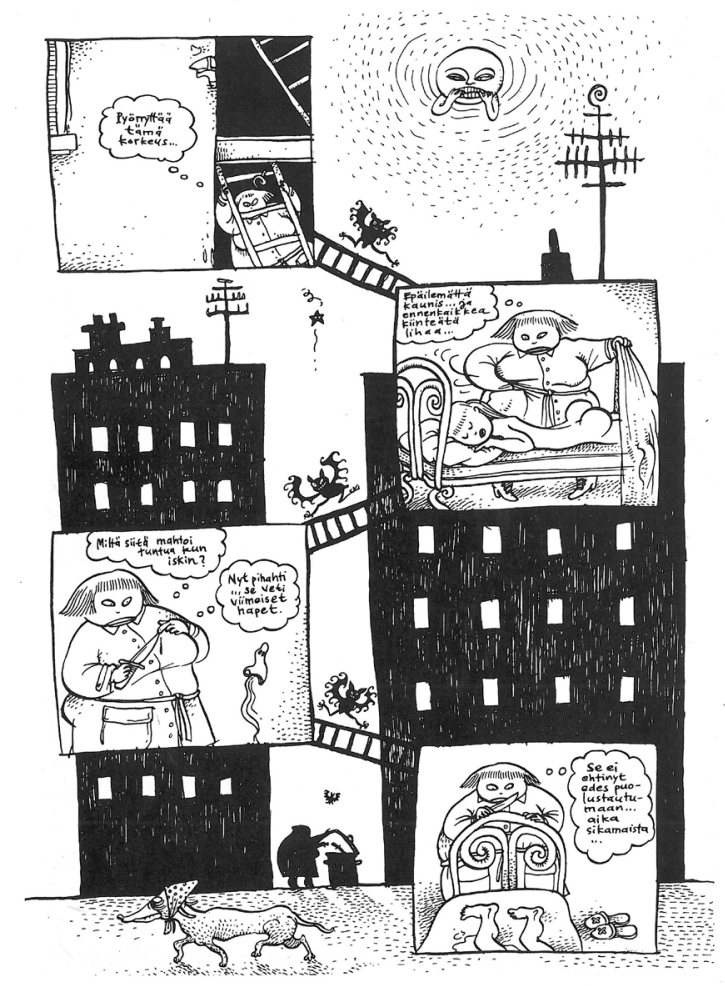

Kuva 1. KS, 14. Julkaistu tekijän luvalla.

\section{Kovácsin teoksen kokeellinen rakenne}

59-sivuinen Karu selli on järjestyksessä Kovácsin toinen sarjakuva-albumi ja edustaa taiteilijan tuotannolle ominaisesti aikuisille suunnattua sarjakuvaa. Teos sisältää yhden kertomuksen, joka on suunniteltu ja julkaistu albumimitassa. ${ }^{1}$ Teosta voi luonnehtia ulkoisen toiminnan sijaan yksilön sisäisten kamppailujen kuvaamiseen keskittyväksi kehityskertomukseksi. Päähenkilö Annabellan kokemusta vankilassa rytmittävät itsereflektiiviset pohdinnat, pahoinvointia aiheuttavat hallusinaatiot ja unennäöt. Piirrostyylillisesti ja sisällöllisesti teoksessa on yhtymäkohtia 1980- ja 1990-luvun kansainväliseen vaihtoehtosarjakuvaan, kuten kanadalaisen Julie Doucet'n ja ruotsalaisen 
Joakim Pirisen symbolisesti kyllästettyihin töihin, joissa kuvataan Kovácsin teosten tavoin toden ja valveen absurdia sekoittumista. ${ }^{2} 1980$ - ja 1990 -luvun taitteessa aloittaneen Kovácsin ura on tunnustettu lukuisin palkinnoin. ${ }^{3}$ Hänen ihmiset liioiteltuina ja karikatyyrisinä hahmoina kuvaava piirrostyylinsä on pysynyt tunnistettavana, mutta uransa aikana hän on kokeillut monenlaisia piirrosvälineitä ja rakenteellisia ratkaisuja sarjakuvakerronnan parissa.

Huolimatta Kovácsin tai lukuisten muiden suomalaisten sarjakuvataiteilijoiden pitkistä urista ja kansainvälisestä näkyvyydestä suomalaisen sarjakuvan muotokieli tai kerronnalliset keinot eivät ole vakiintuneet tutkimuskohteiksi, vaan tutkimus on painottunut sarjakuvan kulttuurihistoriallisiin kytköksiin (Hänninen 2011, 86). ${ }^{4}$ Valtion taidepolitiikassa, apurahajärjestelmissä ja taidekritiikissä sarjakuvan kulttuurinen asema tunnustetaan yhä näkyvämmin (Jokinen 2013, 317). Kovács esimerkiksi oli ensimmäinen sarjakuvataiteilija, jolle vuonna 2014 ensimmäistä kertaa jaettu sarjakuvataiteen valtionpalkinto myönnettiin. Kotimaisen sarjakuvan kulttuurista ja esteettistä asemaa käsittelevissä kirjoituksissa kuvaillaan, kuinka suomalainen sarjakuva on kerronnaltaan ja sisällöltään monipuolista, tasokasta ja kokeilevaa (Hänninen \& Römpötti 2011, 11; Jokinen 2013, 317). Sarjakuva ei ole sidottu yhteen muotoon tai pituuteen, ja alan harrastajalle ovat tuttuja niin sanomalehtisarjakuvat, pitkät sarjakuvaromaanit kuin nettisarjakuvakin. Erilaisten formaattien lisäksi sarjakuva hyödyntää vaihtelevasti erilaisia kerronnallisia ja rakenteellisia keinoja tarinallisista aineksista puhumattakaan. Tämän vuoksi on tarpeellista tutkia yksittäisiä teoksia, jotta edetään sarjakuvien yleisten ominaisuuksien tai "sarjakuvallisten" elementtien kategorisoimisesta täsmällisempiin havaintoihin ja päätelmiin, jotka edesauttavat sarjakuvantutkimusta.

Kovácsin Karu selli -teos on rakenteeltaan kokeellinen, ainakin jos sarjakuva mielletään peräkkäin asettuviksi ruuduiksi, kuten vertaukset elokuvataiteeseen vihjaavat. Ruutujen peräkkäisyys on yksi sarjakuvaa kerrontamuotona luonnehtivimmista rakenteellisista ominaisuuksista, ja usein ruudut muodostavat sivulle ruudukon, joka voi koostua symmetrisistä tai vaihtelevan kokoisista ruuduista. Sarjakuvakriitikko ja -käsikirjoittaja Benoît Peeters (2007) ehdottaa neljän kategorian mallia sarjakuvan sivusommittelujen analysoimiseen. Mallissa erotetaan toisistaan perinteisemmiksi mielletyt ruutusommittelut, jotka voivat ensinnäkin olla säännönmukaisia ja symmetrisiä tai toiseksi retorisia, jolloin ruutujen mittasuhteet riippuvat kuvatuista tapahtumista. Ruutu saattaa venyä leveyttä esimerkiksi, kun kuvauksen kohteena on laaja ihmisjoukko tai kaventua, kun tarkoituksena on välittää tapahtuman lyhyt kesto. Kolmannessa ja neljännessä kategoriassa korostuu sivusommittelujen esteettisyys: koristeellinen sivusommittelu muodostaa itsenäisen esteettisen järjestyksen eikä sitä ole suunniteltu palvelemaan kertovuutta. Tuottavassa sivusommittelussa sommittelu on niin hallitsevassa asemassa, että se jopa määrää ja määrittää kertomuksen sisältöä. (Peeters 2007; ks. myös Baetens \& Frey 2015, 108; Groensteen 2007, 93; Mikkonen 2005, 296.) 
Kovácsin teoksessa on monia sivusommitteluja, joissa ruutujako ei ole sen enempää säännönmukainen kuin retorinenkaan. Karun sellin sivusommitelmat vaihtelevat yhden ison kuvan sisältävästä sivusta useita ruutuja hyödyntäviin sivuihin, jotka ruudukon sijaan koostuvat esimerkiksi isosta taustakuvasta ja sen päälle asettuvista ruuduista. Teoksen rakenteellinen kokeellisuus näkyy myös ruutujen välisessä tilassa, joka perinteisesti on sarjakuvakerronnassa tyhjä. Päähenkilön mielessä itävät murhasuunnitelmat kasvavat koko sivua halkovaksi piikkikasviksi, ja Annabellan vapaudesta eristävät vankilan kalterit konkretisoituvat ruutuja erottaviksi sivusommitelman elementeiksi. ${ }^{5}$ Kasvit, kalterit ja ruutujen välissä vilistävät hyönteiset ovat teoksessa keino kuvata Annabellan mielenliikkeitä mustasukkaisesta kostonhimosta vapaudenkaipuuseen. Kovácsin teos venyttää ja kokeilee sarjakuvakerronnan rajoja, mutta samalla se myös osoittaa Peetersin luokittelun kaltaisten välineiden deskriptiivisen heikkouden: jako säännölliseen, retoriseen, koristeelliseen tai tuottavaan sivusommitteluun ei vielä kerro, mitä kerronnallista tarkoitusta valittu sivusommittelu palvelee yksittäisessä teoksessa. Siksi ehdotankin Karun sellin sivusommittelujen analysoimista suhteessa päähenkilön kokemuksen kuvaukseen.

\section{Sarjakuvahahmon ruumiillinen kokemus tilassa}

Kovácsin teoksessa rakenteellinen tilankäyttö palvelee kokemuksen kuvausta, joka keskittyy päähenkilö Annabellaan. Rakenteellisella tilalla viittaan sivusommitelmien tasoon, mutta teoksessa tilallisuus saa myös monia muita, metaforisempia merkityksiä. Teos ohjaa metaforiseen lukutapaan jo kaksoismerkityksellä leikkivässä nimessä. Yhtäältä 'karu selli' viittaa konkreettisesti Annabellan vankeusympäristöön, toisaalta se viittaa metaforisesti mielen muodostamaan eriöön, jossa kokemukset, muistot ja tapahtumat kiertävät kehää kuluneissa urissa päätyen aina lähtöpisteeseen. Nimen kaksoismerkitys kiteytyy visuaalisesti teoksen kansikuvassa, jossa Annabella istuu keskiakselin varassa pyörivässä karusellissa. Huvilaitteelle tyypillisten ratsujen sijaan rakennelmaa dominoivat kalterit, joiden taakse päähenkilö jää. Mielen metaforinen kuvaus pyörivänä karusellina saa sanallisen muodon päähenkilön äidiltään saamien runojen muodossa: "[p]yörii, pyörii karuselli värikkäiden valojen huumassa. Pyörii, pyörii pääsi harmaissa seinissä. Karu on sun sellisi." (KS, 25.) Annabellan saamissa runoissa sanallistuvat karusellin loppumaton liike ja päättymätön matkanteko, mutta niissä asettuvat vastakkain myös värikkyys ja harmaus. Värikkäästä ja iloisesta karusellista on lyhyt matka harmaaseen, päänsisäiseen selliin.

Inhimillisen kokemuksen kuvaaminen on kertomuksentutkija Monika Fludernikin (1996, 26-27) mukaan kertomusten keskeisin ominaisuus. Kertomukset eroavat esimerkiksi raporteista juuri siitä syystä, että ensin mainitut keskittyvät inhimillisten toimijoiden kuvaamiseen, kun taas jälkimmäiset koostuvat tapahtumien listauksista. 
Kokemuksen kuvaamisen painottaminen kertomusta määrittävänä ominaisuutena tarkoittaa Fludernikin näkemyksessä tapahtumien dynamiikan jättämistä toissijaiseksi. Toiminnan sijaan Fludernik painottaa henkilöhahmojen ruumiillista läsnäoloa, havainnoimista ja reflektoimista. Hän käyttää sanaa kokemuksellisuus (experientiality) viittaamaan siihen, kuinka kertomukset pyrkivät kuvaamaan inhimillisiä kokemuksia, jotka rakentuvat ruumiillisuuteen perustuvalle kokemuspohjaiselle tiedolle. Marco Caracciolo $(2015,15)$ huomauttaa, että kokemuksellisuuden käsitettä on käytetty kahdessa toisistaan huomattavasti poikkeavassa merkityksessä. Yhtäältä sillä on viitattu kokemuksen tekstuaalisiin representaatioihin eli siihen, miten henkilöhahmojen kokemuksia kuvataan. Toisaalta sen avulla on pyritty tarkastelemaan kertomusten lukijoiden kognitiivisia kykyjä tulkita ja ymmärtää. Koska tavoitteenani on sarjakuvakerronnan ilmaisukeinojen analysointi ja ymmärtäminen, painopiste omassa artikkelissani on ensin mainitussa näkökulmassa. Sarjakuvahahmojen ruumiit representoidaan kuvallisesti, mutta miten kuvataan niiden kokemuksellista ruumiillisuutta?

Karun sellin henkilöhahmon edesottamuksia kuvataan kuvallisesti ruuduissa, joista suurimmassa osassa henkilöhahmo esiintyy. Teosta voidaankin pitää huomattavan henkilöhahmokeskeisenä kuvalliselta kerronnaltaan. Sarjakuvahahmojen ruumiin kuvaus edellyttää aina tilallisuutta, minkä vuoksi ruumiillisuus, kokemuksellisuus ja tilallisuus kytkeytyvät sarjakuvakerronnassa toisiinsa. Tilallisuus on keskeinen sarjakuvan ominaisuus sarjakuvaruutujen vaatiessa sivulta paikan sekä tietyn määrän tilaa. Tilallisuus voidaan ajatella sarjakuvavälineen ominaisuudeksi, mutta se voidaan ymmärtää myös sarjakuvien analysoimisessa käytettäväksi käsitteeksi, joka auttaa huomioimaan, kuinka merkitykset rakentuvat kuvallisten ja sanallisten elementtien tilallisessa suhteessa toisiinsa. Sarjakuvateoreetikko Thierry Groensteenin (2007, 34-35) vaikutusvaltaisessa tilallis-paikallisuuden teoriassa sarjakuva käsitetäänkin järjestelmäksi, jonka jokainen elementti on osa laajempaa kokonaisuutta. Sivutasolla tämä tarkoittaa sitä, että yksittäistä sarjakuvaruutua luetaan, merkityksellistetään ja tulkitaan suhteessa sivukokonaisuuteen.

Groensteenin mallia seuraten pidän sarjakuva-analyysin lähtökohtana elementtien välisten tilallisten suhteiden tarkastelua. Analyysissa ei tällöin ole huomionarvoista ainoastaan se, miten ruudut asettuvat lineaarisiksi riveiksi, vaan myös se, miten eri elementit suhteutuvat toisiinsa allekkain ja ristikkäin. Elementtien väliset merkityssuhteet rakentuvat Groensteenin $(2007,18,146)$ teorian mukaan myös laajemmin: jokainen ruutu on ainakin mahdollisessa suhteessa kaikkiin teoksen muihin ruutuihin. Hän kutsuu vierekkäisten ruutujen välisiä suhteita rajatuksi niveltymiseksi (restrained arthrology) ja viittaa koko teoksen muodostamaan kokonaisuuteen yleisenä niveltymisenä (general arthrology). Sarjakuva-analyysi rakentuu Groensteenin mallissa sipulimaisen kerroksittain, jolloin sisemmän ja pienemmän elementin, eli stripin, ja ulkokerroksen, 
eli koko teoksen, väliin sijoittuu sivukokonaisuuksien kerros (spatio-topical system). Eri tasojen nimeäminen palvelee analyyttistä tarvetta rajata tutkimuskohde tarkasteltavissa oleviin osiin: yksittäisistä ruuduista muodostuviin strippeihin, sivukokonaisuuksiin ja koko teoksen dynamiikkaan. ${ }^{6}$ Groensteenin malli ei ota huomioon sarjakuvahahmojen tilallista kuvaamista vaan keskittyy laajempiin rakenteisiin. Kun tulkinnan lähtökohdaksi otetaan Fludernikin käsitys kokemuksellisuudesta kertomusten ydinalueena, on henkilöhahmojen ruumiiden kuvauksen ohittaminen mahdotonta.

\section{Kokemus kuvallisesti kehystettynä}

Kovácsin teoksen kerronta rakentuu retrospektiivisen minäkerronnan varaan. Sanallinen kertoja kehystää ruuduissa nähtävän henkilöhahmon kokevaksi minäksi, jonka edesottamuksia kertova minä selostaa menneessä aikamuodossa (ks. myös Romu 2014b). Teoksen alussa kuvallisesti ja sanallisesti esitelty kerrontatilanne rakentaa teoksen läpi kantavan minäkerronnan kehyksen, joka säilyy vaikka kertovat tekstilaatikot hetkittäin katoavat (vrt. Mikkonen 2008, 313). Sanallinen kertoja kehystää henkilöhahmon kokemuksen kerronnallisesti, mutta teoksen alussa alkaa myös konkreettinen kehystäminen kuvallisten ruutukehysten muodossa. Koristeelliset kehykset ovat Kovácsin teoksessa silmiinpistävä ominaisuus, joka esiintyy vaihtelevasti ensimmäisestä ruudusta alkaen. Kun henkilöhahmo esitellään teoksen alussa, ruutua kehystävät ruoka-aineet ja herkut tukevat minäkertojan luonnehdintaa itsestään aamusta iltaan "mussuttavana" kotirouvana. Kehykset rajaavat ruudut konkreettisesti, mutta niillä on myös metaforisempi kehystämisen merkitys. Päähenkilö Annabellan kokemusta symboloivat koristekehykset leimaavat ruudut subjektiivisuudella: tältä henkilöhahmosta tuntuu ja näin hän tarinamaailman kokee. Kotirouvaksi itsensä esittelevän Annabellan päiviä rytmittää herkkujen syöminen, mutta murhasuunnitelman itäessä kehysten symboliikka muuttuu: kehykset alkavat vilistä uuden ympäristön tutuksi tekemiä otuksia, kuten kovakuoriaisia, kärpäsiä ja muita hyönteisiä. Kun Annabella mustasukkaisuuden puuskassaan varjostaa miehensä rakastajattareksi luulemaansa tyttöä, hänen ikävät ajatuksensa kuvataan ruudun reunuksessa luikertavien käärmehahmojen avulla (KS, 12, ks. Kuva 2). Kehys tuottaa Annabellan kokemuksen kuvaukseen tason, joka ei paljastu Annabellan ruumiin ulkoisesta kuvauksesta. Nurkan takana piileskelevän Annabellan kasvoilta paistaa ilmeettömyys, mutta symboliset käärmeet leimaavat Annabellan olemisen katalaksi ja murhanhimoiseksi. Kärmeiden lisäksi kehyksissä luikertelee muualla teoksessa muun muassa kastematoja, jotka viittaavat vaarallisuuteen liitettyjen käärmeiden sijaan pienuuden ja mitättömyyden kokemuksiin. 


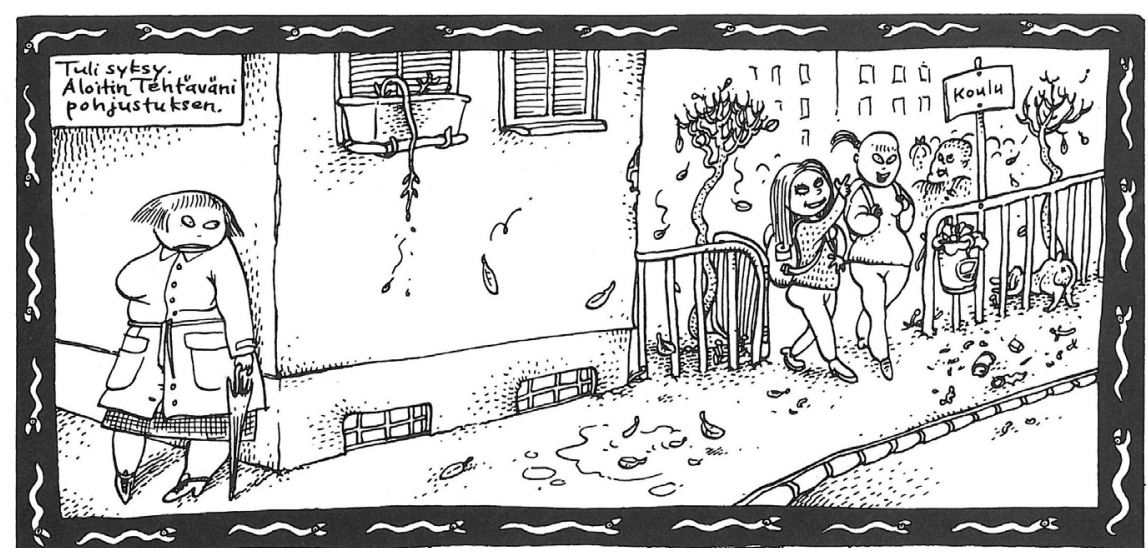

Kuva 2. KS, 12 (yhden ruudun katkelma). Julkaistu tekijän luvalla.

Symbolisia otuksia vilisevät ruutukehykset sananmukaisesti kehystävät henkilöhahmon kokemuksellisuutta yhdessä teoksessa käytetyn sanallisen kerronnan kanssa. Ruutukehykset ovat teoksessa harvinaisen paljon käytetty kerronnallinen keino, joka tuottaa lisätason kuvissa nähtävän kokevan minän ja sanallisesti kertovan minän tasojen rinnalle. On kuitenkin mahdotonta määritellä, kuvaavatko ruutukehykset kokevan minän tuntemuksia, jolloin käärmeet kuvastaisivat Annabellan kokemusta varjostamisen hetkellä, vai ovatko ne pikemmin kertovan minän keino värjätä kokevan minän toiminta, jolloin käärmeiden käyttäminen kehyksissä olisi minäkertojan keino korostaa menneen minän luonteen kurjuutta ja heikkoutta tapahtumien hetkellä. Tämä kehysten kaksoisfunktio ei välttämättä ole ongelma kertomusta tulkittaessa vaan osoittaa teoksen monitulkintaiset mahdollisuudet.

Ruutukehysten symbolinen käyttö on kohtuullisen harvinaista sarjakuvakerronnassa, mutta vertailevana teoksena Karun sellin tavalle käyttää kehyksiä voidaan pitää ranskalaisen David B:n omaelämäkerrallista sarjakuvateosta Epileptikko (2013), jossa kertojan veljen epileptinen ruumis valtaa ruutujen sisäisen tilan lisäksi myös ruutujen kehykset. Sairaus vaikuttaa koko perheen elämään ja "kehystää" sen, mikä kuvataan konkreettisesti ruutukehysten koristeellisella käytöllä. Veljen sairaudesta tulee kertojan näkemyksen mukaan koko perheen elämää tiukasti otteessaan pitävä ilmiö, joka ei rajoitu ainoastaan veljen fyysiseen ruumiiseen, vaan lävistää jokapäiväisen arkitodellisuuden. Kovács ei ole muissa teoksissaan käyttänyt koristeellisia kehyksiä samassa märin kuin Karussa sellissä, jonka kertomus sijoittuu korostetusti päähenkilön mielen sisälle. Symbolisten kehysten käyttö tukee kertomuksen psykologista fokusta. Kehyksissä esiintyvien otusten symbolimerkitysten lisäksi kehykset osallistuvat teoksen visuaalisen rytmin tuottamiseen. Teoksessa käytetyille kehyksille on ominaista pyörivän liikkeen tuottaminen: käärmeet, kastemadot ja muut otukset asettuvat kehyksissä jonoiksi 
ja jatkumoiksi, jotka näyttävät etenevän kehystä pitkin ilman alkua tai loppua. Koristeellisten kehysten päättymättömät symboliketjut ja niistä muodostuva liikkeen vaikutelma tukevat karusellin lailla pyörivän mielen kuvausta.

\section{Murha tapahtuu ruutujen välissä}

Kehysten lisäksi päähenkilön kokemuksellisuuteen liittyvä liike syntyy laajemmin teoksen sivukokonaisuuksissa. Murhaa kuvaavalla sivulla tapahtumat esitetään taustakuvan päälle asetettujen neljän ruudun avulla (ks. Kuva 1). Murhakohtauksen ensimmäisessä ruudussa päähenkilö kiipeää ylös tikapuita, ja huimauksesta kertova ajatuskupla vihjaa päähenkilön olevan todennäköisesti jossain korkealla. Toisessa ruudussa Annabella on löytänyt uhrinsa sängystä nukkumasta ja toteaa tytön olevan kaunis ja "ennen kaikkea kiinteätä lihaa”. Mustasukkaisuuteen sekoittuu kateus nuoreksi rakastajattareksi luullun tytön elinvoimaisuutta kohtaan. Kolmannessa ruudussa on jälleen ainoastaan Annabella, joka pohtii miltä tytöstä mahtoi tuntua veitseniskun ja viimeisen hengenvedon hetkellä. Viimeinen ruutu näyttää sängyn jalkopäässä seisovan päähenkilön, joka katsoo kuvasta suurimmaksi osaksi ulos rajautuvaa ruumista ja pohtii tekonsa raukkamaisuutta.

Annabellan ajatuksista saadaan murhaa kuvaavalla sivulla tietoa ajatuskuplien avulla. Päähenkilö kokee hienoisia tunnontuskia murhattuaan puolustuskyvyttömässä tilassa olleen tytön. Ajatus- ja puhekuplat ovat yleisiä keinoja henkilöhahmojen kokemusten ja ajatusten välittämiseen, mutta välineen visuaalisuudesta johtuen keinot ovat myös kuvallisia. Sanallisen kuvailun sijaan henkilöhahmojen ruumiit ovat keskeisiä tajunnankuvauksen paikkoja asentojen, ilmeiden ja eleiden lukemattomien kuvausvariaatioiden ansiosta (Mikkonen 2008, 303). Annabellan kasvot näyttävät koko sivun ajan ilmeettömiltä, mutta hänen halunsa ymmärtää uhrin kokema kipu välittyy eleessä, jossa hän pistää itseään veitsen kärjellä ikään kuin hän voisi oman ruumiillisen reaktionsa avulla ymmärtää tekonsa. Huolimatta henkilöhahmon silmiinpistävästä keinotekoisuudesta pelkistettyine ja muutamista viivoista koostuvine piirteineen Annabellalla esitetään olevan ruumiillinen kokemus. Ruumiillisuus on Fludernikin (1996, 30) mukaan kokemuksellisuuden ja siten myös kertomusten keskiössä: ruumiillisen läsnäolomme ja sitä kautta maailmasta saadun tiedon avulla voimme ymmärtää myös fiktiivisiä henkilöhahmoja. Kun Annabella pohtii, miltä tytöstä mahtoi tuntua kuoleman hetkellä, lukija voi yrittää kuvitella, mitä Annabella tuntee pistäessään itseään veitsellä. Annabellan kuvauksessa näyttäisivät toteutuvan Fludernikin $(1996,30)$ kokemuksellisuuden keskeisimmät edellytykset: ihmishahmo on läsnä ympäristössä, ja saamme tietää hänen kokemuksestaan ja emotionaalisesta sekä fyysisestä reaktiostaan ympäristöön. Sen sijaan murhan uhrin ajatukset ja kokemukset jäävät vaille kuvausta, sillä hänen ruumiinsa kirjaimellisesti rajataan ruudun ulkopuolelle. 
Murhaa kuvaavan sivun tilallinen rakenne on yhteydessä vallitsevaan konventioon lukemisen suunnasta. Tapahtumien kronologisen jatkumon ymmärtäminen edellyttää, että sivun ruudut luetaan vasemmasta yläkulmasta oikeaan alakulmaan päätyen. Neljällä ruudulla esitetään päh̆henkilön toiminnan vaiheet mutta myös hänen pohdintansa teon moraalisuudesta. Huomionarvoista on se, että itse murhaa ei sivulla näytetä, vaan ainoastaan uhriin kohdistuva tarkastelu ja Annabellan reaktio tekoonsa. Viitteitä tytön murhasta antavat toki kolmannessa ruudussa kummitusmainen hahmo, joka voidaan tulkita uhrin ruumiista erkanevaksi sieluksi, sekä neljännessä ruudussa nähtävät tytön jalat, jotka lepäävät veren tahrimalla vuoteella. Itse kuolinisku ja murhan hetki kuitenkin rajautuvat ruutujen ulkopuolelle. Murha sijoittuu ruutujen väliin, ja veriteon yksityiskohtaisuus jää lukijan mielikuvituksen varaan. Ruutujen väliin jäävä tila on toiminut sarjakuvatutkimuksessa eräänlaisena symbolina sarjakuvan edellyttämälle lukijan aktiivisuudelle: ruutujen välisessä tilassa lukija täydentää kuvaamatta jääneet tapahtumat. ${ }^{7}$ Ruutujen väliin jäävä murha on klassinen esimerkki sarjakuvateoriassa, kun on haluttu havainnollistaa lukijalta vaadittavan täydentämisen merkitystä sarjakuvakertomusten ymmärtämisessä (ks. McCloud 1993, 66-68). Kovácsinkin teos leikittelee näyttämisen ja näyttämättä jättämisen välisellä jännitteellä: murhasta vihjataan monin eri tavoin, mutta veitsen iskeytyminen uhrin ruumiiseen jätetään kuvaamatta.

Ruuduissa näkyvän informaation lisäksi lukija pystyy toki päättelemään murhan tapahtuneen suhteuttamalla tapahtuneen tarinan edeltäviin ja seuraaviin tapahtumiin. Murhasuunnitelmasta vihjataan aiemmin kertomuksessa Annabellan ajatuskuplissa, jotka ennakoivat kostonhimoisen päähenkilön dramaattisia ratkaisuja: "[m]inun täytyy tappaa... / ...se Oona" (KS, 10). Lisäksi murhaa edeltää pitkällinen varjostusoperaatio (ks. Kuva 2), jossa tyttö paljastuu elintavoiltaan äärimmäisen säännölliseksi: jopa tikkukaramellin nauttimiselle on varattu jokaisesta päivästä oma hetkensä. Murhakohtauksen jälkeen Annabella nähdään jatkamassa arkista elämäänsä aviomiehensä kanssa. Huomattavaa on vain ero päähenkilön itseluottamuksessa ja elämänasenteessa: mustasukkaisuuden kourissa kärvistelevä murhaaja on kilpailijan eliminoituaan muuttunut aviomiestä herkkuruuilla ja erotiikkaa tihkuvalla tanssiesityksellä hemmottelevaksi kotirouvaksi.

Ruutujen sisällön ja kontekstin lisäksi lukijaa ohjataan murhaa kuvaavan sivun taustakuvassa. Ruutujen sommittelusta muodostuva siksak-kuvio ohjaa lukijan viimeiseksi taustakuvan alareunassa olevaan mustaan silhuettiin. Ruumiinrakenteeltaan Annabellaa muistuttava hahmo heittää veitseltä näyttävää esinettä roska-astiaan. Kerrostalojen väliin muodostuu ikään kuin sivun viides ruutu, joka sinetöi tapahtumaketjun kuvaamalla murhakertomuksissa tyypillisesti toistuvan kohtauksen murha-aseen hävittämisestä. Silhuettihahmo myös ohjaa päättelemään Annabellan palaavan tytön luota, vaikka sitä ei itse ruuduissa näytetä. Ruutujen järjestys ja kerronnallista jatkuvuutta tuottava henkilöhahmon toistuminen ohjaavat lukijaa muodostamaan kausaalisen ja kronologisen tapahtumaketjun. 


\section{Kokemus ruutujen muodostamassa tapahtumaketjussa}

Kokemuksellisuutta korostavassa kertomuksen tulkintamallissa toiminta ei ole ensisijainen kertomusta määrittävä tekijä. Sarjakuvan lukemisen on kuitenkin ehdotettu perustuvan tapahtumaketjujen ensisijaistamiselle (Groensteen 2007, 124). Kausaalisuuden painottaminen antaa olettaa, että lukija kiinnittää huomiota ainoastaan toiminnan kannalta merkityksellisiin yksityiskohtiin, kuten Groensteen (mt.) ehdottaa. Groensteenin ohella myös sarjakuvateoreetikko Pascal Lefèvre $(2000,5)$ korostaa toimintaan keskittyvän lukuskeeman hallitsevuutta. Hän kirjoittaa, että kausaalisuus ja kronologisuus sarjakuvaruutuja yhdistävinä tekijöinä ovat lukijan muodostamia skeemoja, joiden avulla lukija rakentaa merkityssuhteen peräkkäisten ruutujen välille. ${ }^{8}$ Toisaalla Lefevre $(2011,16)$ lisää, että perinteisesti sarjakuvat on suunniteltu nopeasti luettaviksi, mikä selittää nopeasti tunnistettavien ja stereotyyppisten elementtien käytön. Groesteenin ja Lefèvren ajatusten taustalla näkyy käsitys sarjakuvasta tapahtumavetoisena kertomuksena tai syy-seurausketjuna, jossa on alku, keskikohta ja loppu. Kokemuksellisuutta korostavan kertomuskäsityksen valossa myös sarjakuvien lukeminen näyttäytyy moniulotteisempana toimintana kuin tapahtumaketjujen rekisteröintinä. Vaikka monet perinteiset sarjakuvat olisikin suunniteltu nopeaan lukemiseen, tätä ominaisuutta ei voida laajentaa koskemaan kaikkea sarjakuvaa ja ohittaa siten eri genrejen ja taiteilijoiden väliset erot ja ominaispiirteet.

Kovácsin teoksen sivulla on paljon sellaista, mitä ainoastaan ruutujen kausaalisiin tai kronologisiin suhteisiin kiinnittyvä lukija ei huomaisi. Yksityiskohtainen piirrosjälki on Kovácsin tavaramerkki, kuten myös hänen tapansa käyttää tarinan tapahtumien kannalta epäolennaisilta vaikuttavia hahmoja, kuten inhimillistettyjä tarinamaailman objekteja. Murhaa kuvaavalla sivulla öistä kaupunkia kansoittavat hampaitaan kirskutteleva kuu, irvistävät lepakot ja kadulla maleksiva huivipäinen koira. Minäkerronnan kehys tuottaa asetelman, jossa kokemuksellisuuden käsite vaikuttaa käyttökelpoiselta työvälineeltä analysoitaessa teosta värittävää symboliikkaa. Läpi teoksen Annabella rinnastetaan erilaisiin eläimiin ja olentoihin joko samankaltaisuuden, yhdistämisen tai lähekkäin asemoimisen avulla. Annabella kuvataan esimerkiksi toistuvasti kovakuoriaisena, ja kuten totesin, hänen kostonhimoiset ajatuksensa saavat symbolisen muodon käärmeiden hahmossa.

Murhaa kuvaavalla sivulla vilistävien mielikuvituksellisten olentojen tulkitseminen Annabellan kokemuksellisuuden symbolisina kuvaajina mahdollistaa luennan ruutuja yhdistävästä ilkeännäköisestä lepakosta eräänlaisena Annabellan kostonhimon ruumiillistumana, versiona olkapäällä istuvasta pirusta. Yön pimeydessä saalistava eläin on kansanperinteestä lähtien liitetty pahuuteen. Lukijan katseen viimeiseksi sivulla tavoittava huivipäinen koira voisi vastaavasti visuaalisesti symboloida päähenkilön kokemusta: murhaaja luikkii pois rikospaikalta päästen "kuin koira veräjästä". Tulkintaa tukee 
koiran sijoittuminen tilallisesti veistä roskikseen heittävän Annabellan läheisyyteen ja koiran asuste, joka muistuttaa päähenkilön aiemmin käyttämää huivia. Vaikka kaikki sivun elementit ovat nähtävissä simultaanisesti, niiden saamat merkitykset riippuvat siitä, millaista tilallista polkua pitkin lukijan katse ohjataan ja mitä polun varrella on. Sommitelman kerroksellisuus rakentuu ruutujen ja taustakuvan yhteistyössä, jossa ruuduista muodostuvaan murhaa kuvaavaan kausaaliketjuun limittyvät metaforisesti ja symbolisesti kuvatut henkilöhahmon kokemukset.

\section{Sivun ja tarinamaailman tilallinen analogisuus}

Kuten huomioin edellä, kuvallinen esittäminen antaa lukijalle tietoa henkilöhahmon ilmeistä ja asennoista. Toiseksi henkilöhahmon kuvaaminen tarinan tilassa näyttää, kuinka henkilöhahmo suhteutuu ympäristöönsä ja miten hän sitä havainnoi. Kolmanneksi henkilöhahmon toistuva kuvaaminen helpottaa lukemista: toiston avulla Annabellan ruumiista muodostuu sivulla - ja laajemmin teoksessa - lukemista rytmittävä ankkuri, johon lukijan katse ohjautuu. Henkilöhahmojen asennot ja katseet muodostavat sarjakuvakerronnassa yleensäkin lukijan katsetta ohjaavia linjoja, joita kuvatutkimuksessa on kutsuttu vektoreiksi. Vektorit muodostuvat usein toiminnan suuntaisesti, joten ne myös auttavat lukijaa kerronnallistamaan näkemäänsä (Kress \& van Leeuwen 2006, 59, 63). Kovácsin teoksessa henkilöhahmon tilallinen sijoittuminen sivukokonaisuuteen nähden tuottaa vaikutelman henkilöhahmon ruumiillisesta liikkeestä. Vektoreita katseellaan seuratessaan lukija ei ainoastaan etene sarjakuvasivulla eteenpäin, vaan vektoreiden avulla rakentuu Kovácsin teoksissa sivukokonaisuuteen henkilöhahmon kokemuksellisuuden taso.

Taustakuvan vuoksi sivulla käytetty sommittelu poikkeaa perinteisesti sarjakuvakerronnassa käytetystä ruudukosta. Ratkaisua voidaan pitää alussa mainitsemani Peetersin (2007) jaottelun mukaisesti koristeellisena keinona tuottaa teoksen rakenteeseen monipuolisuutta. Kokemuksellisuuden näkökulmasta ruutusommittelulla on kuitenkin merkitys henkilöhahmon ruumiillisten kokemusten rakentajana ja vahvistajana. Annabellan huimausta kuvaava ruutu on sijoitettu kerrostalojen ylle, jolloin rakenteellinen tila tehostaa Annabellan toimintaa tarinamaailman tilassa. Sivun vertikaalisuutta käytetään luomaan vaikutelma henkilöhahmon liikkeestä ympäristössään: vertigo syntyy, kun Annabella näkee alaspäin katsoessaan rakennusten välisessä tilassa häämöttävän maanpinnan. Sarjakuvasivun ja tarinamaailman tilan käyttäminen analogisessa suhteessa on juuri kokemuksellisuuden rakentamisen sarjakuvallinen keino. Esimerkiksi yhdysvaltalainen sarjakuvataiteilija Craig Thompson käyttää vastaavaa keinoa Habibi-teoksessaan $(2012,216)$ kuvatessaan päähenkilön vaarallista ja vauhdikasta pakomatkaa korkealta palatsin katolta alas pihan suihkulähteeseen. Katon ja suihkulähteen korkeusero on kuvattu rakentamalla tilallinen ero myös sarjakuvasivun 
tilassa, jolloin liike korkeuserojen välillä korostuu. Thompsonin teoksessa vauhdikasta liikettä korostavat ja päähenkilön pakomatkaa myötäilevät myös diagonaaliset ruutuvälit, ruutujen asettelu ja siitä syntyvä lukusuunta. Karun sellin esimerkissä sivun ylälaita vastaa analogisesti Annabellan sijoittumista tarinamaailman tilassa korkealle. Seuraavien ruutujen asemointi ei kuitenkaan enää tue Annabellan ruumiin asettumista korkealla sijaitsevaan kerrostaloasuntoon. Vaikka Annabella pysyy huoneistossa, ruutu ruudulta laskeudutaan sivun tilassa, kunnes viimeinen ruutu sijoittuu katutasoon.

Sivusommittelussa rakentuva tarinamaailman ja sivun tilan analogisuus tukee vaikutelmaa, jonka mukaan Annabella kiipeää tikkaat ylös ja palaa niitä pitkin myös alas. Ruutuja yhdistävät tikkaat toimivat symbolisena kuvaajana, joka kuvaa sitä kuinka Annabella laskeutuu tarinamaailman tilassa takaisin maan tasalle. Tikkaat yhdistävät ruudut toisiinsa ja ohjaavat lukijan katsetta ruudusta toiseen, joten tikkaat toimivat myös vektorin tehtävässä. Henkilöhahmon ruumiillista liikettä myötäilevä, tukeva ja rakentava sivusommittelu toistuu teoksessa, kun vankilaan joutunut Annabella kärsii sellinsä yksinäisyydessä, näkee hallusinaation ja sen seurauksena oksentaa (KS, 26-27). Yhdellä aukeamalla kuvattu kokonaisuus ohjaa lukijan katsetta ensimmäisellä sivulla vaakatasossa, toisella sivulla katseen suunta ohjataan vertikaaliseksi: pystytason sijaan sivu on jaettu kolmeen osaan vaakatasoisesti. Rakenteellinen tila tukee henkilöhahmon kokemuksen kuvausta, jossa epätoivosta äänetöntä huutoaan karjuva Annabella ensin kyykistyy sellinsä lattialle, sitten nousee ylös aggressiivisen hallusinaation voimasta ja viimein kouristuu kaksin kerroin oksentamisen voimasta. Murhaa kuvaavan sivun tavoin kohtauksessa käytetään kokeellisia sarjakuvakerronnan elementtejä myös ruutuja erottavien elementtien osalta: ruutuja erottavat toisistaan jättimäiset kalterit, joiden suuntaus muuttuu sivulta toiselle ikään kuin korostaen henkilöhahmon kokemusta hallusinaation todellisuudentajua muuttavasta voimasta.

Kokeelliset sivusommittelut tukevat molemmissa esimerkeissä sitä, mitä Karin Kukkonen (2013a, 61; 2013b, 49) on kuvaillut sarjakuvan kyvyksi kuvata kokemusta ruumiillisuuden kautta. Hän pyytää kiinnittämään huomion siihen, miten henkilöhahmojen tilallinen asemointi suhteutuu tarinamaailman parametreihin: millaista liikettä henkilöhahmojen ruumiiden asemointi ja sivusommittelu rakentavat? Sivusommittelussa rakentuva liike on yksi mahdollisuus rakentaa henkilöhahmojen ruumiillista kokemuksellisuutta. Karun sellin murhaa kuvaava sivu on monitasoinen liikkeen kuvauksessaan, sillä liike on sivulla simultaanisesti kahdenlaista. Lukijan on mahdollista muodostaa ensinnäkin ruutujen sisältöjen kuvaama Annabellan liike tytön huoneessa ja toiseksi sivusommittelussa toteutuva Annabellan vertikaalinen liike kerrostalon palotikkailla. On vaikea kuvitella, miten vastaava kaksitasoinen liike voitaisiin toteuttaa esimerkiksi elokuvakerronnassa. Kyseessä on sarjakuvakerronnalle mahdollinen rakenne, joka perustuu kerrontavälineen tilallis-paikallisuudelle ja sille, että lukijan katsetta ohjataan sivulla. 


\section{Murha olikin valetta}

Teoksen loppuun edetessään lukija joutuu yllätetyksi: murhaa ei tapahtunutkaan, ja Annabella herää sairaalassa. Uhriksi kaavailtu tyttö on löytänyt Annabellan talonsa palotikkaiden juurelta, ilmeisesti putoamisen seurauksena loukkaantuneena. Onnettomuus on aiheuttanut vuoden kestävän koomatilan, jossa Annabellan alitajunta on rakennellut kuvitelmia murhasta ja sitä seuranneesta vankilaepisodista. Loppuratkaisun yllättämä lukija voi palata murhaa kuvaavalle sivulle, jolloin myös tulkinnat sivun rakenteesta ja visuaalisista elementeistä voivat muuttua. Tulkinnan karuselli, jonka kyydissä lukija yrittää pysytellä, nirskahtaa urallaan teoksen alkuun, ja kehämäisyys toteutuu siten temaattisen tason lisäksi myös tulkinnan tasolla.

Teoksen lopun yllätyksellisyys murhan paljastumisesta päähenkilön mielensisäiseksi tapahtumaksi kannustaa tutkimaan uudestaan, mitä murhaa kuvaavalla sivulla oikeastaan tapahtuu. Palattaessa lopusta takaisin murhakohtaukseen tulkintakehyksenä ei ole enää onnistunut kostoretki, vaan päähenkilön subjektiivinen näkemys siitä, miten hänen suunnitelmansa olisi pitänyt toteutua. On totta, että murhasta vihjataan melko eksplisiittisin keinoin: Annabella löytää tytön sängystä nukkumasta, ja päähenkilön ajatuskuplat kertovat hänen tuntemistaan epäilyksen ja katumuksen tunteista. Kuten jo kirjoitin, varsinaista veitseniskua ei kuitenkaan kuvata.

Teoksen retrospektiivisestä kerrontapositiosta huolimatta lukijalle ei anneta sanallisia vihjeitä murhayrityksen epäonnistumisesta. Klassisen narratologian mukaan retrospektiiviseen kerrontapositioon liittyy kerronnan ja kokemisen ajallinen etäisyys, mistä johtuu, että kertova minä myös tietää enemmän kuin kokeva minä (Cohn 1978, 143). Ajallisesta etäisyydestä huolimatta Karun sellin minäkertoja identifioituu läheisesti kokevan minän positioon. Teoksen lopussa koettava yllätys perustuukin vahvasti tiedolliseen hierarkiaan, jossa kertoja säätelee lukijan saamaa informaatiota. Murhaa kuvaavalla sivulla sanallista kertojaa ei ole, vaan kertomus etenee kuvallisesti; päähenkilön ajatuskuplat sisältävät ainoat sanalliset elementit. Sanallisen kerronnan täydellinen poissaolo murhaa kuvaavalla sivulla etäännyttää hetkellisesti tapahtumien todellisesta käänteestä tietoisen kertovan minän. Sanallisen kerronnan puuttuessa minäkertojaa ei voida perinteiseen tapaan syyttää epäluotettavaksi, ainakaan jos kerronnan agentin ymmärretään koostuvan vain tekstilaatikoiden välittämästä "äänestä”, sillä murhan ajaksi sanallinen kertoja vaikenee. ${ }^{?}$

Edellä väitin, että lukijan katseen ohjaaminen yhdessä kausaaliketjun muodostumisen kanssa tukee tulkintaa, jonka mukaan Annabella palaa tytön luota heitettyään ensin murha-aseen roskikseen. Vasten loppuratkaisun tuottamaa tietoa ruutusommittelu ei tue Annabellan paluuta tytön luota, vaan rakenteellisen tilan ja tarinamaailman tilan analoginen suhde ja lukijan katseen ohjaus ylhäältä alas korreloivatkin Annabellan putoamisen kanssa. Ensimmäisen ruudun huimaus asettuu uuteen tulkinnalliseen 
valoon: huimaus ei ole ohimenevä kokemus, vaan se on syynä Annabellan putoamiseen. Ensimmäisen ruudun alapuolelle on sijoitettu pieni tähti, josta lähtevät spiraaliviivat toistavat Annabellan pään yllä nähtävän viivan muotoja. Sarjakuvakerronnassa henkilöhahmon pään yllä nähtävää tähteä käytetään henkilöhahmon pökertyneisyyttä tai tajunnan menetystä kuvaavana efektinä (Herkman 1998, 46). Konventiosta tietoinen lukija tulkitsee tähden näkymättömiin jätetyn tapahtuman eli Annabellan putoamisen merkitsijänä. Sivun kokonaisuuden kannalta pieneltä vaikuttavasta elementistä tulee eräänlainen silmänisku lukijalle, joka haluaa loppuratkaisun jälkeen palata tarkastelemaan harhaanjohtamisen kohtaa. Teoksen lopussa paljastuva tieto koomasta antaa myös metaforisille elementeille lisää tulkintavaihtoehtoja: jos tytön luota ei kerran palaakaan Annabella, ovatko lepakot metafora Annabellan karkuteille juoksevalle mielelle ja pupillittomasti tyhjää tuijottava koira Annabellan kooman vangiksi joutuvan ruumiin kuva, eräänlainen tyhjä kuori?

\section{Lopuksi}

Sarjakuvien visuaalisuus edellyttää henkilöhahmojen ruumiiden kuvaamista, mitä voidaan pitää yhtenä keskeisenä sarjakuvan asettamana haasteena ja antina kertomuksen ja kokemuksellisuuden tutkimukselle (ks. myös Chute 2015). Havaitseva, tunteva ja kokeva henkilöhahmo asettuu sarjakuvassa osaksi tarinamaailmaa ruumiin eleiden, liikkeiden, ilmeiden ja asentojen kautta. Fludernikin kokemuksellisuuden käsitettä hyödyntävässä tulkinnassani olen osoittanut, että Kovácsin teoksen rakenteelliset ratkaisut ovat sarjakuvallinen keino tukea päähenkilön sisäiseen kehitykseen ja minuuden syövereihin keskittyvää kehityskertomusta. Kokemuksellisuutta tulee tässä mielessä ajatella laajempana ilmiönä kuin sarjakuvahahmojen ulkonäön kuvauksena.

Murhakohtauksessa käytetty sivusommittelu on rakenteeltaan teoksessa ainutkertainen. Teos sisältää monia muita kokeellisia ja perinteisistä ruutusommitelmista poikkeavia sivuja, joiden rakennetta olen toisaalla tutkinut yhteydessä sivuilla kuvattuihin tapahtumiin (Romu 2014a; 2014b). Kovácsin teoksessa rakennetaan kerrontatilanne, jossa retrospektiivisen minäkertojan ääni kehystää koko kertomusta. Äänen poissaolo murhaa kuvaavalla sivulla poistaa hetkellisesti ajallisen etäisyyden ja korostaa kokevan minän toimintaa tapahtumien hetkellä. Kuten sivun rakenteen analyysini osoittaa, myös sivulla rakentuvilla liikesuunnilla ja rakenteellisen tilan analogisella suhteella tarinamaailman tilaan tuetaan lukijan tulkintaa murhan tapahtumisesta ja päähenkilön pakenemisesta murhapaikalta. Teoksen luettuaan harhautettu lukija voi todeta, että sen enempää sanallinen kertoja kuin kuvallinen esityskään eivät eksplisiittisesti väittäneet murhan tapahtuneen. Lukijaa kuitenkin ohjattiin tulkitsemaan näin.

Kovácsin teos sisältää kokeellisia ratkaisuja poikkeuksellisen paljon, mutta analyysissa tekemiäni huomioita voidaan soveltaa myös esimerkiksi omaelämäkerrallisiin 
sarjakuviin, joissa kuvataan kertovan ja kokevan subjektin tajuntaa. Kuten analyysini on osoittanut, sarjakuvan keinot kokemuksellisuuden kuvaamiseen eivät ole ainoastaan kuvallis-sanallisia vaan myös rakenteeseen liittyviä. Karun sellin tapainen monikerroksinen sarjakuva edellyttää sekä lukijalta että tutkijalta yksityiskohtiin pysähtymistä. Jos teosta luetaan kausaalisten tai kronologisten ruutujen ketjuna, menetetään teoksen tulkinnasta paljon. Ruutujen muodot ja asemoinnit sivulla, sommitelmiin rakentuvat katseen ohjaamisen keinot ja metaforiset kuvaelementit osallistuvat päähenkilön kokemuksellisuuden kuvaukseen tavalla, joka on mahdollinen ainoastaan sarjakuvan tilallis-paikallisessa rakenteessa.

\section{Viitteet}

${ }^{1}$ Pitkistä sarjakuvista käytetään usein lajinimikettä sarjakuvaromaani (graphic novel), jolla halutaan kertoa kyseessä olevan kerronnallisilta keinoiltaan, sisällöltään, julkaisuformaatiltaan ja tuotannolliselta taustaltaan muista sarjakuvista poikkeava muoto (ks. Baetens \& Frey 2015, 8-19). Termi on ymmärretty kuitenkin usein myös arvottavana, minkä vuoksi useat tutkijat välttävät sitä ja puhuvat yleisemmin sarjakuvakertomuksista. Sarjakuvatutkija Hillary Chute $(2008,453)$ huomauttaa, että sarjakuvaromaani ei terminä kata alleen omaelämäkerrallisia sarjakuvia, minkä vuoksi hän suosii sarjakuvakertomuksen (graphic narrative) nimitystä. Tarvetta sarjakuvaromaanin tai -kertomuksen käsitteille selittää englanninkielinen termi comics, joka viittaa humoristisuuteen. Tällaista painolastia ei ole suomenkielisellä sarjakuvatermillä, joka viittaa sisällöllisten ominaisuuksien sijaan muotoon, kuvien peräkkäisyyteen. ${ }^{2}$ Kovács on maininnut ihailevansa Doucet’n ja Pirisen töitä, vaikkakin vaikutteet hänen töihinsä tulevat taiteilijan mukaan sarjakuvien lisäksi kuvataiteesta ja kirjallisuudesta (Hänninen \& Römpötti 2011, 61). Mainittujen sarjakuvataiteilijoiden välille voi kuitenkin vetää yhteyden siinä, miten he kaikki käsittelevät yhteiskunnallisia tabuaiheita, kuten normista poikkeavaa seksiä ja seksuaalisuutta, usein groteskillakin tavalla. Lisäksi heidän sarjakuvissaan seikkailevat hahmot usein kyseenalaistavat toiminnallaan vallitsevan järjestyksen tai saattavat sen naurunalaiseksi. Pirinen tuli tunnetuksi erityisesti lapsenomaisen ja anarkistisen SokeriSakari -hahmonsa kautta (Pirinen 1987), Doucet omaelämäkerrallisista sarjakuvistaan ja sarjakuvamuotoon piirretyistä unikertomuksistaan (esim. Doucet 1994). Suomalaisessa sarjakuvassa absurdius ja surrealismi näkyivät myös 1990-luvulla sarjakuvia tehneen Anu Lavosen kertomuksissa ja laajemmin pienlehdissä, kuten Suuressa Kurpitsassa (1981-1993) ja Sarjarissa (1981-).

${ }^{3}$ Kovácsin laajaa tuotantoa on käännetty ruotsiksi, saksaksi, ranskaksi ja unkariksi. Karu selli on käännetty ruotsiksi vuonna 1997 (Karu cell) ja saksaksi vuonna 1998 (Karussell). Kovácsin työ sarjakuvan parissa on tunnustettu muun muassa opetusministeriön Nuoren taiteen Suomi -palkinnolla (1996), Suomen sarjakuvaseuran myöntämällä Puupäähattu-palkinnolla (1999), Kemin pohjoismaisen sarjakuvakilpailun Grand Prix'llä (2001), Lempi Grand Prix'llä (2004), Sarjakuva-Finlandialla (2011) ja sarjakuvataiteen valtionpalkinnolla (2014). Albumien lisäksi Kovács on tehnyt sarjakuvia myös sanoma- ja aikakauslehtiin yhdessä sarjakuvakäsikirjoittaja Pauli Kallion kanssa sekä käsikirjoittanut ja ideoinut nukkeanimaatioelokuvan Lisa Limone and Maroc Orange: A Rapid Love Story (2013). 
${ }^{4}$ Sarjakuvan muotokieltä ovat tutkineet Suomessa muiden muassa Pekka A. Manninen (1995), Juha Herkman (1998), Kai Mikkonen (esim. 2005, 2008), Karin Kukkonen (2010) ja Katja Kontturi (2014), mutta heidän tutkimuksensa eivät ole keskittyneet kotimaiseen sarjakuvaan. Tutkimuksissa sarjakuvakerronnan analysointi yhdistyy usein sarjakuvan kulttuurisen aseman tarkasteluun (esim. Arffman 2004; Miettinen 2012). Suomalaisen sarjakuvan sosiologista historiaa on tutkinut Ralf Kauranen (2008).

${ }^{5}$ Suomalaiseen sarjakuvaan suuresti vaikuttanut Tove Jansson hyödynsi innovatiivisesti välipalkkeja strippeinä etenevissä muumisarjakuvissaan, mutta pidemmissä sarjakuvissa kyseinen keino on harvinaisempi. Juhani Tolvanen $(2000,97)$ kirjoittaa, että Jansson aloitti "välipalkkivallankumouksen" ensimmäisessä, 1950-luvulla julkaistussa muumien seikkailua kuvaavassa jatkosarjassaan, jossa hän käytti jopa 26 erilaista tarinamaailman esinettä jakamaan sarjakuvaruutuja. Kovács jatkaa Janssonin perinnettä, mutta soveltaa sitä pitkän sarjakuvakertomuksen tarpeisiin.

${ }^{6}$ Myös sanallisia elementtejä tulee sarjakuvassa tarkastella sivukokonaisuuden sommitelmallisina osina. Niiden asemoiminen ohjaa lukijan katsetta sivulla, ja sanojen merkitys kiinnittyy niiden kuvalliseen kontekstiin. Sanallista kerrontaa ei siten voida ajatella äänenä, jolla ei olisi tilallista ulottuvuutta. (Ks. Romu 2014b, 136-137.)

${ }^{7}$ Ruutuvälistä (engl. gutter eli katuoja) on tullut myös symboli sarjakuvan kulttuuriselle asemalle eri taidemuotojen välissä. Jared Gardner (2012, xi) käsittää ruutuvälin eräänlaisena kurittomuuden ja kapinan symbolina, joka kuvaa hänen mukaansa hyvin korkeakulttuurin ulkopuolelle jäänyttä sarjakuvaa.

${ }^{8}$ Kognitiivisesta tutkimuksesta peräisin olevaa skeeman käsitettä on kertomusten tutkimuksessa käytetty tulkinnallisen kehyksen merkityksessä. Lukijan aiempi tietämys toimii kognitiivisena apuvälineenä kehystäen uutta informaatiota ja tehden siitä ymmärrettävämpää. Näkemyksen mukaan kirjallisuuden ymmärtämisessä käytetään aktiivisesti tosielämästä tuttuja kognitiivisia kehyksiä. (Ks. Branigan 1992, 13; Fludernik 1996, 12.)

${ }^{9}$ Kysymykseen kertovan agentin luonteesta on sarjakuvatutkimuksessa kehitetty monenlaisia malleja. Thierry Groensteen (2013, 79-97) ehdottaa sanallisen ja kuvallisen kertojan käsittämistä toisistaan erillisiksi agenteiksi, joita kerronnan hierarkiassa korkeammalla tasolla oleva kertoja hallinnoi. Tällainen kuvan ja sanan erottaminen osoittautuu kuitenkin mahdottomaksi analysoitaessa Karun sellin kaltaista teosta, jossa sanallinen minäkertoja vaikuttaa olevan tietoinen kuvallisesta esitystavasta (Romu 2014b, 133).

\section{Kirjallisuus}

Arffman, Päivi 2004. "Comics go underground!" Underground-sarjakuva vastakulttuurina vuosien 1967-1974 Yhdysvalloissa. Turku: k\&h, Turun yliopisto, kulttuurihistoria.

B. David 2013. Epileptikko. (L'Ascension du Haut-Mal, 2005.) Suom. Saara Pääkkönen. Helsinki: WSOY.

Baetens, Jan \& Hugo Frey 2015. The Graphic Novel. An Introduction. Cambridge: Cambridge University Press.

Branigan, Edward 1992. Narrative Comprehension and Film. London \& New York: Routledge. 
Caracciolo, Marco 2015. Experientiality. Peter Hühn, John Pier, Wolf Schmid \& Jörg Schünert (eds.), the living handbook of narratology. Hamburg: Hamburg University. http://www.lhn.uni-hamburg.de/article/experientiality (14.2.2016).

Chute, Hillary 2008. Comics as Literature? Reading Graphic Narrative. PMLA 123(2), 452-465.

Chute, Hillary 2015. The Space of Graphic Narrative. Mapping Bodies, Feminism, and Form. Robyn Warhol \& Susan S. Lanser (eds.), Narrative Theory Unbound. Queer and Feminist Interventions. Columbus: The Ohio State University Press, 194-209.

Cohn, Dorrit 1978. Transparent Minds. Narrative Modes for Presenting Consciousness in Fiction. Princeton: Princeton University Press.

Doucet, Julie 1994. Jos olisin mies ja muita kertomuksia. Suom. ja toim. Pauli Kallio ja Reija Nieminen. Tampere: Suuri Kurpitsa.

Fludernik, Monika 1996. Towards a 'Natural' Narratology. London: Routledge.

Gardner, Jared 2012. Projections. Comics and the History of Twenty-First-Century Storytelling. Stanford: Stanford University Press.

Groensteen, Thierry 2007. The System of Comics. (Système de la bande dessinée, 1999). Trans. Bart Beaty \& Nick Nguyen. Jackson: University Press of Mississippi.

Groensteen, Thierry 2013. Comics and Narration. (Bande dessinée et narration: Système de la bande dessinée 2, 2011). Trans. Ann Miller. Jackson: University Press of Missisippi.

Herkman, Juha 1998. Sarjakuvan kieli ja mieli. Tampere: Vastapaino.

Hänninen, Ville 2011. Roskakulttuuri saapui akatemian portaille - suomalaisen sarjakuvakirjoittamisen ja -tutkimuksen vaiheita. Heikki Jokinen (toim.), Sarjakuva Suomessa. Historiasta, asemasta, kielestä. Helsinki: Avain, 77-95.

Hänninen, Ville \& Harri Römpötti 2011. Päin näköä! 16 suomalaista sarjakuvataiteilijaa. Helsinki: Like.

Jokinen, Heikki 2013. Suomi tunnusti sarjakuvan. Mika Hallila, Yrjö Hosiaisluoma, Sanna Karkulehto, Leena Kirstinä \& Jussi Ojajärvi (toim.), Suomen nykykirjallisuus 1-Lajeja, poetiikkaa. Helsinki: Suomalaisen Kirjallisuuden Seura, 317-325.

Kauranen, Ralf 2008. Seriedebatt i 1950-talets Finland. En studie i barndom, media och reglering. Turku: Åbo Akademis förlag/Åbo Akademi University Press.

Kontturi, Katja 2014. Ankkalinna - portti kahden maailman välillä. Don Rosan Disneysarjakuvat postmoderneina fantasiasarjakuvina. Jyväskylä studies in humanities 255. Jyväskylä: Jyväskylän yliopisto.

Kovács, Kati 1996. Karu selli $[=K S]$. Helsinki: Arktinen Banaani.

Kress, Gunther \& Theo van Leeuwen 2006 (1996). Reading Images. The Grammar of Visual Design. London \& New York: Routledge. 
Kukkonen, Karin 2010. Storytelling Beyond Postmodernism. Fables and the Fairy Tale. Acta Universitatis Tamperensis 1499. Tampere: Tampere University Press.

Kukkonen, Karin 2013a. Studying Comics and Graphic Novels. Chichester: Wiley Blackwell.

Kukkonen, Karin 2013b. Space, Time, and Causality in Graphic Narratives. An Embodied Approach. Jan-Noël Thon \& Daniel Stein (eds.), From Comic Strips to Graphic Novels. Contributions to the Theory and History of Graphic Narrative. Berlin: De Gruyter, 49-66.

Lefevre, Pascal 2000. Narration in Comics. Image [\&] Narrative. Online Magazine of the Visual Narrative, 1:1. http://www.imageandnarrative.be/inarchive/narratology/ pascallefevre.htm (14.2.2016).

Lefevre, Pascal 2011. Some Medium-Specific Qualities of Graphic Sequences. SubStance 124, 40(1), 14-33.

Manninen, Pekka A. 1995. Vastarinnan välineistö. Sarjakuvaharrastuksen merkityksiä. Tampere: Tampere University Press.

McCloud, Scott 1993. Understanding Comics. The Invisible Art. New York: HarperPerennial.

Miettinen, Mervi 2012. Truth, Justice, and the American Way? The Popular Geopolitics of American Identity in Contemporary Superhero Comics. Acta Universitatis Tamperensis 1790. Tampere: Tampere University Press.

Mikkonen, Kai 2005. Kuva ja sana. Kuvan ja sanan vuorovaikutus kirjallisuudessa, kuvataiteessa ja ikonoteksteissä. Helsinki: Gaudeamus.

Mikkonen, Kai 2008. Presenting Minds in Graphic Narratives. Partial Answers 6(2), 301-321.

Peeters, Benoît 2007 (1998). Four Conceptions of the Page. From Case, planche, récit: lire la bande dessinée. Trans. Jesse Cohn. ImageTexT: Interdisciplinary Comics Studies. 3.3. http://www.english.ufl.edu/imagetext/archives/v3_3/peeters/ (14.2.2016).

Pirinen, Joakim 1987. Sokeri-Sakari. (Socker-Conny, 1985.) Suom. Jukka Heiskanen. Helsinki: Jalava.

Potsch, Elisabeth \& Robert F. Williams 2012. Image Schemas and Conceptual Metaphor in Action Comics. Frank Bramlett (ed.), Linguistics and the Study of Comics. Basingstoke: Palgrave Macmillan, 13-36.

Romu, Leena 2014a. Ruutuja rikkovat ruumiit Kati Kovácsin sarjakuvassa Karu selli. Suomen kirjallisuuden lisensiaatintutkielma. Tampereen yliopisto. http://tampub. uta.fi/handle/10024/96690 (14.2.2016). 
Romu, Leena 2014b. Tämännäköisiä naisia ja ironisia ääniä - kerronnan jännitteet Kati Kovácsin sarjakuvissa Karu selli ja Kuka pelkää Nenian Ahnavia?. Mikko Höglund, Tommi Kakko, Mervi Miettinen, Hanna Parviainen \& Paul Rickman (toim.), Word and Image. Theoretical and Methodological Approaches. Tampere Studies in Language, Translation and Literature, Series B2. http://urn.fi/URN:ISBN:978-951-44-9689-9 (14.2.2016).

Thompson, Craig 2012. Habibi. (Habibi, 2011.) Suom. Ida Takala. Helsinki: Like Kustannus Oy.

Tolvanen, Juhani 2000. Muumisisarukset Tove ja Lars Jansson. Muumipeikko-sarjakuvan tarina. Helsinki: WSOY. 